\title{
PENERAPAN MODEL PEMBELAJARAN MAKEA MATCH UNTUK \\ MENINGKATKAN HASIL BELAIAR SISWA PADA MATAPELAJARAN IPS DI KELAS V SD
}

\author{
Masta Ginting \\ Surel : mastaginting01@gmail.com
}

\begin{abstract}
ABSTRAK
dengan Penelitian ini bertujuan untuk meningkatkan hasil belajar siswa Pengumpulanggunakan desain PTK dan menggunakan dua siklus. Pengumpulan data dilakukan dengan tes dan observasi. Data yang terkumpul penelitian ini yakni siswa persentase dan analisis kualitatif. Subjek dalam hasil penelitia dari siswa kelas $V$ yang berjumlah 25 orang. Berdasarkan klasikal siswan dari 25 orang siswa pada saat tes awal tingkat ketuntasan 20 sikal siswa kelas $V$ sebanyak 5 orang siswa $(20 \%)$ sedangkan sebanyak klasikal 46.42 . $(80 \%)$ belum mendapat nilai tuntas dengan nilai rata-rata tuntas 46.42 . Pada siklus I sebanyak 10 orang siswa $(40 \%)$ mendapat nilai dengan nilai sebanyak 15 orang siswa $(60 \%)$ belum mendapat nilai tuntas $(84 \%)$ mend rata-rata klasikal 60,01 . Pada siklus II sebanyak 21 orang siswa belum mapat nilai tuntas, sedangkan sebanyak 4 orang siswa $(16 \%)$ .
\end{abstract}

Kata Kunci : Hasil Belajar, Make A Match, IPS

\section{PENDAHULUAN}

Pendidikan IPS mempunyai peran dalam mengubah tingkah laku anak didik agar menjadi manusia dewasa yang hidup mandiri dan sebagai anggota masyarakat yang berkarakter dalam lingkungan masyarakat. Pendidikan tidak hanya mencakup pengembangan intelektualitas saja, akan tetapi lebih ditekankan pada proses pembinaan kepribadian anak didik secara menyeluruh sehingga anak menjadi lebih dewasa dalam bersikap dan berprilaku.

Berdasarkan Identifikasi masalah di atas, maka masalah dalam penelitian ini dapat dibatasi yaitu pada " Meningkatkan hasil belajar siswa dengan menggunakan model pembelajaran Make A Match pada mata pelajaran IPS materi pokok
Peristiwa Menjelang Kemerdekaan di Kelas V SD Negeri 106163 Bandar Klippa".

Adapun tujuan dari pada penelitian ini adalah untuk meningkatkan hasil belajar siswa dengan menggunakan model pembelajaran Make A Match pada mata pelajaran IPS materi pokok Peristiwa Menjelang Kemerdekaan di Kelas V SD Negeri 106163 Bandar Klippa.

Manfaat yang diambil dari hasil penelitin ini adalah:

a. Bagi siswa, sebagai bahan masukan bagi siswa yang dalam meningkatkan hasil belajar siswa itu sendiri.

b. Bagi guru, sebagai bahan masukan dalam meningkatkan keterampilan guru dalam mengembangkan model 
pembelajaran kooperatif moxtel mate a marth dalam mata pelajaran IPS

c. Bagi sekolah, hasil penelitian ini dapat menjadi referensi sebagai masukan dan evaluasi guna meningkatkan mutu dan kuatilas pendidikan di SD Negeri 106163 Bandar Klippa

d. Bagi peneliti, dapat mengembangkan wawasan dan pengalaman peneliti dalam peningkatan kualitas pembelajaran

e. Bagi peneliti lain, menjadi referensi sebagai masukan untuk perbandingan bagi peneliti lain yang meneliti permasalahan yang sama.

\section{METODE PENELITIAN}

Jenis penelitian ini adalah Penelitian Tindakan Kelas (Classroom Action Research). Penelitian tindakan kelas yang dilakukan adalah upaya-upaya yang dilakukan untuk meningkatkan hasil belajar siswa dengan menggunakan strategi pembelajaran make a match.
Lokasi dan Waktu Penelitian

Penelitian ini ditakukan di (1) Negeri 106163 Bandar Klippa semester genap T.A 2015/2016. Waktu penelitian direncanakan pada bulan februari sampai maret 2016

Subjek dan Objek Penelitian

Dalam penelitian ini yang menjadi subjek penelitian adalah Siswa Kelas Va SD Negeri 106163 Bandar Klippa yang berjumlah 25 orang siswa dengan 10 laki-laki dan 15 perempuan. Objek penelitian ini adalah kemampuan hasil belajar siswa terhadap mata pelajaran IPS. Sebagai alternatif tindakan yang diberikan sebagai upaya untuk meningkatkan hasil belajar siswa adalah dengan menggunakan model kooperatif make a match dengan materi pokok Peristiwa Menjelang Kemerdekaan

\section{Desain Penelitian}

Desain penelitian dalam pelaksanaan penelitian ini dapat dijelaskan sebagai berikut: 


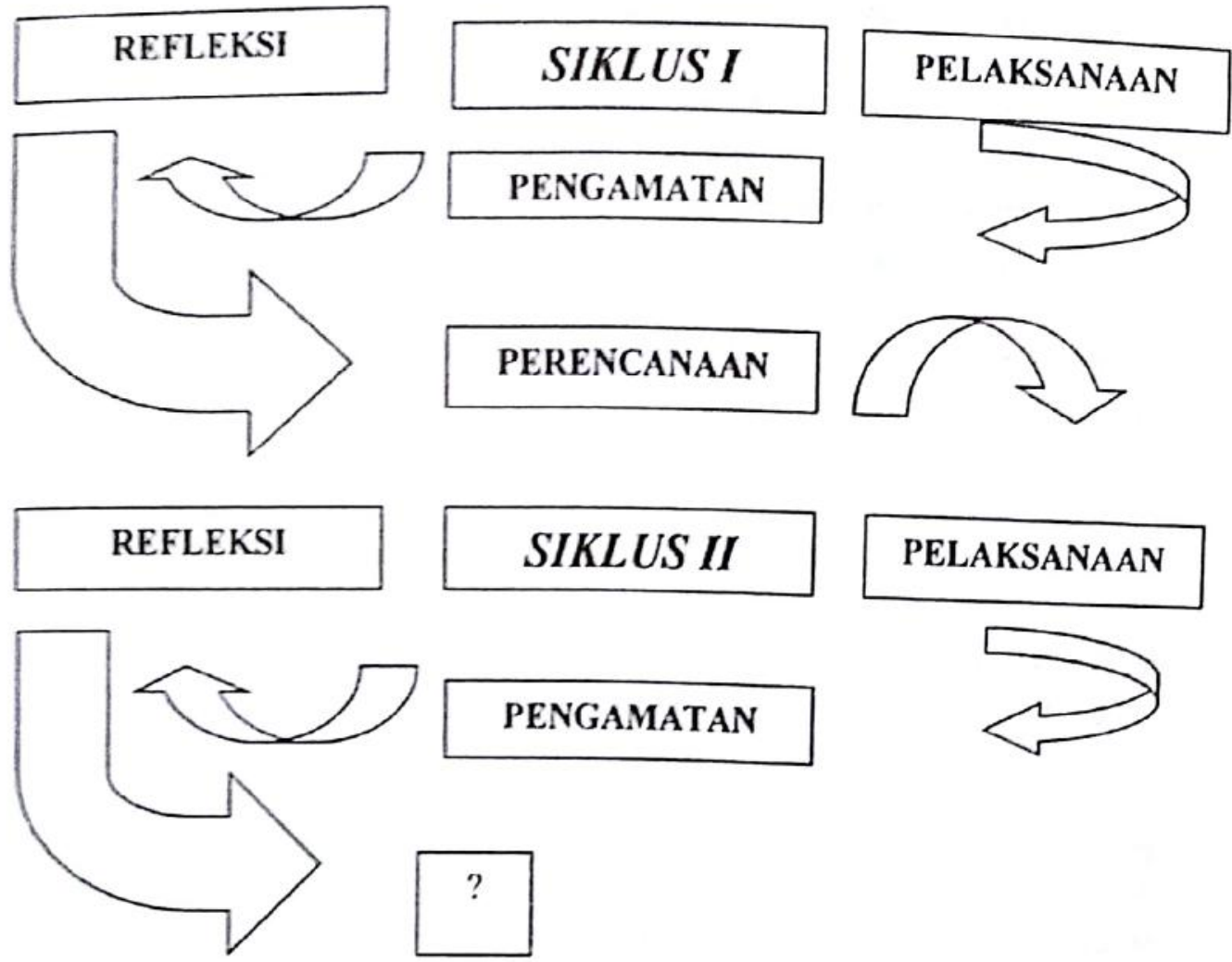

Gambar Pengembangan Penelitian Tindakan Kelas (Rosmala, 2010: 92)

Prosedur Penelitian

\section{SIKLUS I}

Perencanaan

Langkah-langkah kegiatan perencanaan yaitu:

a. Menyusun rencana pembelajaran.

b. Menyiapkan beberapa kartu yang berisi konsep atau materi pelajaran yang akan diajarkan.

c. Menyiapkan waktu yang digunakan dalam menggunakan make a macth.

d. Menyusun lembar pengamatan untuk aktivitas guru dan siswa.

e. Menpersiapkan media pembelajaran yang akan digunakan. f. Mempersiapkan Lembar Kerja Siswa (LKS), soal-soal latihan pretes.

\section{Pelaksanaan}

Langkah-langkah tindakan yang dilakukan adalah sebagai berikut:

a. Guru menyiapkan beberapa kartu yang berisi beberapa konsep atau topik yang cocok untuk sesi review, sebaliknya satu bagian kartu soal dan bagian lainnya kartu jawaban

b. Setiap siswa mendapat satu buah kartu.

c. Tiap siswa memikirkan jawaban/soal dari kartu yang dipegang. 
d. Setiap siswa mencari pasangan yang mempunyai kartu yang cocok dengan kartunya. Artinya siswa yang kebetulan mendapat kartu 'soal' maka harus mencari pasangan yang memegang kartu 'jawaban soal' secepat mungkin. Demikian juga sebaliknya.

c. Setiap siswa yang dapat mencocokkan kartunya sebelum batas waktu diberi poin.

f. Setelah satu babak kartu dikocok lagi agar tiap siswa mendapat kartu yang berbeda dari sebelumnya.

g. Demikian seterusnya sampai semua kartu soal dan jawaban jatuh ke semua siswa.

h. Kesimpulan/penutup.

\section{Pengamatan}

Pada tahap ini, kegiatan yang dilakukan adalah melaksanakan pengamatan kegiatan guru terhadap pelaksanaan tindakan secara khusus dan proses pembelajaran secara umum dengan menggunakan lembar pengamatan yang telah disiapkan

\section{Refleksi}

Refleksi merupakan langkah untuk menganalisis hasil kerja siswa. Analisis dilakukan untuk mengukur baik kelebihan maupun kekurangan yang terdapat pada siklus I.

\section{SIKLUS II}

\section{Perencanaan}

Tahap ini dilakukan seperti

Siklus I.
a. Menyusun
rencana
pembelajaran.

b. Menyiapkan beberapa kartu yang berisi konsep atau topik materi pelajaran.

c. Menyiapkan batas waktu yang digunakan dalam mencari pasangan.

d. Menyusun lembar pengamatan.

e. Menyusun lembar kerja siswa (LKS), soal-soal latihan, pretes.

\section{Pelaksanaan}

$$
\text { Langkah-langkah tindakan }
$$

yang dilakukan adalah sebagai

berikut:

a. Guru menyiapkan beberapa kartu yang berisi beberapa konsep atau topik yang cocok untuk sesi review, sebaliknya satu bagian kartu soal dan bagian lainnya kartu jawaban.

b. Setiap siswa mendapat satu buah kartu.

c. Tiap siswa memikirkan jawaban/soal dari kartu yang dipegang.

d. Setiap siswa mencari pasangan yang mempunyai kartu yang cocok dengan kartunya. Artinya siswa yang kebetulan mendapat kartu 'soal' maka harus mencari pasangan yang memegang kartu 'jawaban soal' secepat mungkin. Demikian juga sebaliknya.

e. Setiap siswa yang dapat mencocokkan kartunya sebelum batas waktu diberi poin.

f. Setelah satu babak kartu dikocok lagi agar tiap siswa mendapat kartu yang berbeda dari sebelumnya.

g. Demikian seterusnya sampai semua kartu soal dan jawaban 
jatuh be struas sicwa.

h. Kesimbulin gerunap.

\section{Pengematsin}

Padh whar inh same hainge dengan sibus of chsernatsi teear dihabulan unake mellate periembangm hesil bethiur siswe selamis pembehajaran dengun menggumakin model pemblhizern

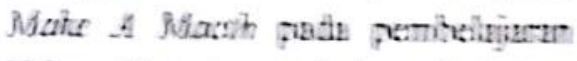
IPS bimen poksk Peristives meriolang kemerdekum.

\section{Reiteksi}

Retiekst merupakan linghah

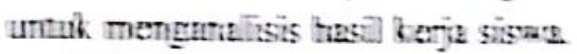
AmaTisis dikakukan umak menguhur haik kelehitam maupun kexuryngen

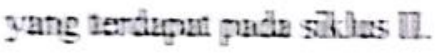

\section{Alzt Pengrmprien Dets}

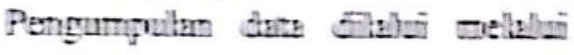
tahap sebagei terikut:

\section{a. Cossenasi

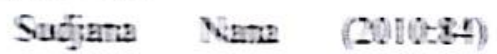

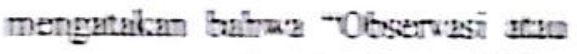
pengarmatum sthagi zha perilain barrak: digunahen umtak mengiur tingkah laicu individu anapon proses tejjading: swat keginn yang dapu diameti bex deln sitursil yang sebemarmya marpu daho sicuasi buatan Obserkasi depar nergukur atan memilai hasil delan proses belajar misalnga tingkah bibu siswa pada waln belsyur, tinglah bion gure paso malts mergajar, kegiatan diskasi sisma partisipesio da penggunan alat peraga pada waktu mengajar. b. Tes

Tes wislah alat untuk memperolich sejath mana kemmpuan sissora tian melthat tingat kebertasilan sisws sari suatu materi sjar yang tehah dixumpuikan setelumnys.

Alas pengumpulan data dalam perrelition int adalah tes yong berbencuk pilitan bergandia 10 butir swel poits pokok bahasan Tokoh. tokive penting Proklamasi Remerdekan. Tes ini borfungsi unnk mengukur kemampuan dan melithat tingkat keberhasilan siswa dengan model pembelajaran moke a monit.

\section{Teknik Analisis Data}

Tekrik analisis data ini menjelaskan data yang diperoleh dianalisis untuk mengetahui hasil akhir. Langkah-langkah teknik analisis daca adalah:

\section{Analisis Duta yang Diperoleh dari Hasil Tes \\ Sebelum hasil belajar diberi} nilai, terlebih dahulu dilakukan penskoran. Penskoran adalah suatu proses mengubah jawaban-jawaban tes menjadi angka-angka (mengadiakan kualifikasi). Penskoran dilakukan agar hasil penilaian menjadi objektif. Rumus yang digunakan untuk penskoran soal pilithan berganda adalah sebagai berikut:

$$
S=\sum R-\frac{\sum W}{n-1}
$$

Reterumgon:

Sumber Purvanto (2011:190) 
$S=$ skor yang dicari

$\Sigma R=$ jumlah soal yang benar

$\Sigma W=$ jumlah skor yang salah

$n=$ jumlah option (alternative jawaban tiap soal)

1 = bilangan tetap

Setelah

dilakuakan

penskoran, langkah selanjutnya adalah member nilai tes hasil belajar dengan menggunakan rumus sebagai berikut:

$$
\mathrm{S}=\frac{R}{\mathrm{~N}} \times 100
$$

\section{Keterangan:}

Sumber Purwanto (2011:207)

$\mathrm{S}=$ nilai yang diharapkan (dicari)

$\mathrm{R}$ =jumlah skor dari item atau soal yang dijawab benar

$\mathrm{N}=$ skor maksimum dari tes tersebut

Dengan kriteria:

$$
\begin{gathered}
\text { Nilai }<70 \begin{array}{c}
\text { siswa belum tuntas } \\
\text { dalam belajar }
\end{array} \\
\text { Nilai } \geq 70 \begin{array}{c}
\text { siswa sudah tuntas } \\
\text { dalam belajar }
\end{array}
\end{gathered}
$$

Dalam hal ini, apabila siswa mendapat nilai dibawah 70 berarti tidak tuntas dalam belajar. Dan sebaliknya, apabila siswa mendapat dilai diatas 70 berarti tuntas dalam belajar.

a. Nilai Rata-Rata Klasikal

Nilai rata-rata ini diperoleh dengan rumus:

$$
\mathrm{X}=\frac{\sum X}{\sum N}
$$

\section{Keterangan:}

Sumber Aqib (2010:40)
$X=$ nilai rata-rata klasikal

$\Sigma X=$ jumlah semua nilai siswa

$\Sigma N=$ jumlah siswa

\section{b. Ketuntasan Belajar Klasikal}

Untuk mengetahui persentase siswa yang sudah tuntas belajar secara klasikal dugunakan rumus:

$$
\mathrm{p}=\frac{\Sigma f}{\Sigma N} \times 100 \%
$$

\section{Keterangan :}

Sumber Aqib (2010:41)

$$
P=\text { Persentase Keberhasilan }
$$

$$
\text { Klasikal }
$$

$\sum f=$ jumlah siswa yang tuntas

$\sum N=$ jumlah siswa seluruhnya

Kriteria untuk peningkatan keberhasilan dari tiap-tiap soal digunakan untuk melihat peningkatan hasil belajar yang dibagi menjadi :

\section{Tabel Kriteria keberhasilan belajar siswa}

\begin{tabular}{|c|c|c|}
\hline No. & Kriteria & $\begin{array}{c}\text { Tingkat } \\
\text { Keberhasilan }\end{array}$ \\
\hline I. & Sangat baik & $>80 \%$ \\
\hline 2. & Baik & $60-79 \%$ \\
\hline 3. & Cukup & $40-59 \%$ \\
\hline 4. & Rendah & $20-39 \%$ \\
\hline 5. & Sangat rendah & $<20 \%$ \\
\hline
\end{tabular}

\section{Sumber Aqib (2010:41)}

Dari persentasi di atas dapat diketahui banyak siswa yang tuntas dalam belajar dan tidak tuntas. Analisis ini dapat dijadikan refleksi untuk melakukan perencanaan pada siklus selanjutnya. 
c. Analisis Hasil Observasi Untuk

Siswa Ditentukan Dengan

Rumus:

$=\frac{\text { Jumlah skor aspei yang diamati }}{\text { lumlah total aspek }} \times 100 \%$

Keterangan

$\mathrm{P}=$ persentase hasil observasi

berikut:

Dengan ketentuan sebagai

Tabel Hasil Observasi Untuk Siswa

\begin{tabular}{|c|c|c|}
\hline $\begin{array}{c}\text { Persentase } \\
\text { Perubahan }\end{array}$ & Keterangan & $\begin{array}{c}\text { Standart } \\
\text { Nilai 4 }\end{array}$ \\
\hline $90-100 \%$ & Sangat Baik & 4 \\
\hline $80-89 \%$ & Baik & 3 \\
\hline $70-79 \%$ & Cukup & 2 \\
\hline$<70 \%$ & Kurang & 1 \\
\hline
\end{tabular}

\section{HASIL PENELITIAN DAN}

\section{PEMBAHASAN}

Penelitian ini dilaksanakan di SD Negeri 106163 Bandar Klippa T.A 2015/2016. Sekolah ini mempunyai luas tanah $1.667 \mathrm{~m}^{2}$. Mempunyai 7 ruang kelas yang berukuran $\pm 49 \mathrm{~m}^{2}$. Sarana lainnya yang mendukung adalah perpustakaan, kantor kepala sekolah sekaligus ruang guru, ruang UKS, toilet, gudang, kantin, rumah dinas.

Penelitian ini dilaksanakan di kelas VSD Negeri 106163 Bandar Klippa T.A 2015/2016. Sebagai subjek dalam penelitian ini adalah siswa kelas V SD Negeri 106163 Bandar Klippa T.A 2015/2016 sebanyak 25 orang. Objek penelitian tindakan kelas ini adalah penggunaan model pembelajaran make a match untuk meningkatkan hasil belajar siswa pada pelajaran IPS materi peristiwa menjelang kemerdekaan.

Deskripsi Data Awal Siswa (Tes Awal)

Langkah awal sebelum
melakukan tindakan penelitian adalah dengan melakukan observasi terhadap siswa. Observasi yang dilakukan untuk mengetahui masalah yang dialami oleh siswa dalam pelajaran IPS materi peristiwa menjelang kemerdekaan. Tes Awaltersebut diberikan kepada siswa kelas VSD Negeri 106163 Bandar Klippa T.A 2015/2016.

Soal Tes Awalyang diberikan dalam bentuk pilihan berganda sebanyak 20 soal. Untuk memberikan nilai nilai kepada siswa terlebih dahulu dilakukan penskoran. Hal ini bertujuan agar hasil penelitian menjadi objektif. Dengan skor tertinggi 20 dan nilai 100. Nilai ketuntasan untuk pelajaran IPS adalah 70. Berdasarkan hasil penelitian di peroleh nilai Tes Awalsebagai berikut :

Dari keseluruhan siswa kelas $\mathrm{V}$ yg berjumlah 25 orang, hanya 5 orang $(20 \%)$ siswa yang tuntas dan sebanyak 20 orang $(80 \%)$ tidak tuntas. Hal ini membuktikan bahwa hasil belajar siswa kelas V secara klasikal belum tuntas karena belum mencapai $80 \%$ tingkat ketuntasan klasikal. Hasil ketuntasan belajar siswa dapat dilihat pada grafik berikut ini: 


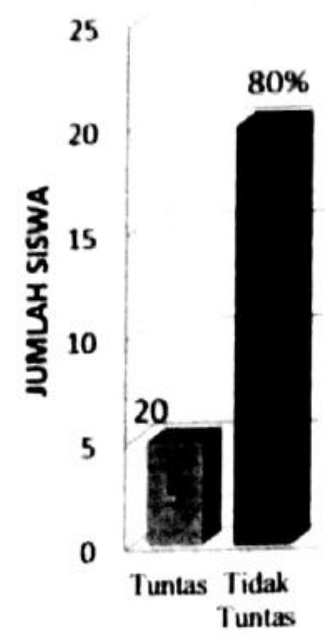

\section{Grafik Persentase Ketuntasan Belajar} Klasikal Pada Tes Awal

Berdasarkan grafik di atas, jelaslah bahwa siswa kelas V SD Negeri 106163 Bandar Klippa T.A $2015 / 2016$ sebanyak $80 \%$ mengalami ketidaktuntasan dalam belajar.

\section{Deskripsi Hasil Penelitian Siklus I}

a. Tahap Perencanaan Tindakan

b. Tahap Pelaksanaan Tindakan

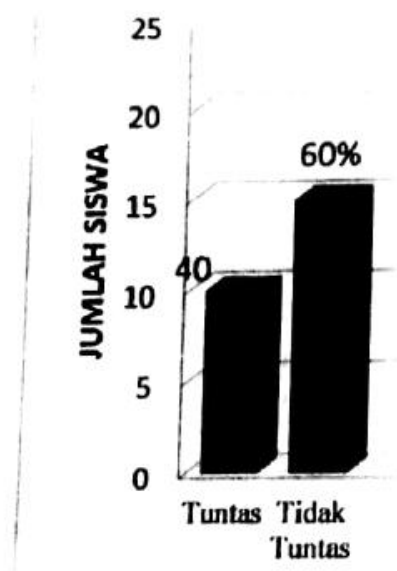

Grafik Persentase Ketuntasan Belajar Klasikal Pada Post Test Siklus I llasil kefuntasan belajar klasikal pada post test siklus II dapat dilihat pada gralik berikut ini:

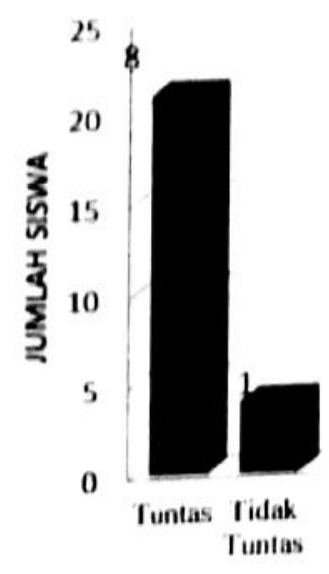

\section{Grafik Persentase Ketuntasan Belajar Klasikal Pada Post Test Siklus II}

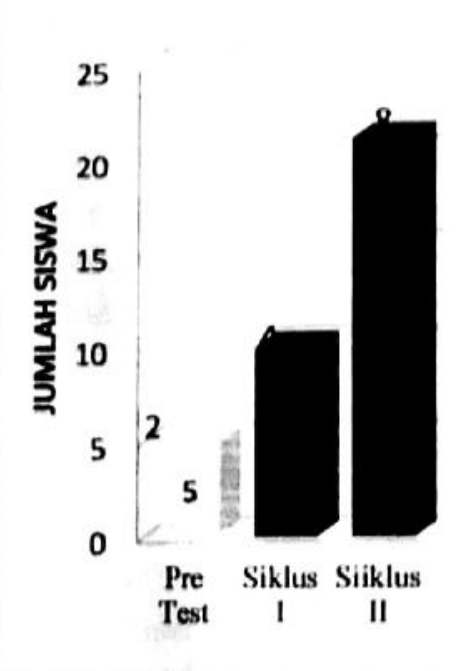

Grafik Grafik Ketuntasan Belajar Pada Tes Awal, Post Test Siklus I dan Siklus II

\section{Pembahasan}

Berdasarkan analisis data yang telah dilakukan pada siklus I dan II, maka dapat dijabarkan bahwa hasil tes awal yang diikuti oleh 25 siswa kelas VSD Negeri 106/63 
Bandar Klippa T.A 2015/2016 pada pelajaran IPS materi peristiwa menjelang kemerdekaan nilai tertingginya adalah 86,7 dan terendah 26,7. Dari 25 siswa hanya 5 orang yang mengalami ketuntasan belajar atau sebesar $20 \%$, sebanyak 20 siswa atau sebesar $80 \%$ siswa tidak tuntas dalam belajar. Dan nilai rata-rata klasikal sebesar 46,42 . Tingkat ketuntasan belajar klasikalnya sebesar $20 \%$. Hal tersebut masih dibawah $80 \%$ ketuntasan yang diharapkan.

Setelah diberi tindakan pada siklus I dengan menggunakan modeI pembelajaran make a match pada pelajaran IPS materi peristiwa menjelang kemerdekaan, diperoleh nilai tertinggi 93,35 dan terendah 33,35. Sebanyak 10 siswa atau sebesar $40 \%$ mengalami ketuntasan belajar, sebanyak 15 siswa atau sebesar $60 \%$ tidak tuntas dalam belajar. Dan nilai rata-rata klasikalnya 60,01 . Ketuntasan belajar klasikalnya $40 \%$. Jika dilihat dari hasil Tes Awal terjadi peningkatan jumlah siswa yang mengalami ketuntasan belajar, akan tetapi tindakan pada siklus I belum bisa dikatakan berhasil karena masih dibawan $80 \%$ ketuntasan yang diharapkan. Hasil observasi aktivitas belajar siswa rata-ratanya sebesar 23,48 . Oleh karena itu dilakukan tindakan perbaikan pada siklus II.

Hasil analisis data pada siklus II, diperoleh nilai tertinggi 100 dan terendah 60. 21 siswa mengalami ketuntasan belajar atau sebesar $84 \%$ dan sebanyak 4 siswa atau sebesar $16 \%$ mengalami ketidaktuntasan dalam belajar. Dengan nilai rata-rata klasikalnya 86,15. Dari data tersebut, ketuntasan belajar klasikal siswa kelas $V$ pada pelajaran IPs erateng sangat tingei dan telah melebihi $80 \%$ keturitasan yang difarapkan. Hal ini menurijukan bahwa, erjadi peningkatan hasil belajar sisua pada siklus II. Dari hasil obveryasi aktivitas belajar siswa pada siklus II rata-ratanya schesar 32 .

berdasarkan hasil perislitian ini dipcrolch gambaran batrwa model pernbelajaran make a motch dapat meningkatkan hasil belajar siswa dalam menyelesaikan sal-soal. Hal ini disebabkan bentuk pelajaran tidak hanya dipusatkan kepada guru semata yang berperan aktif akan tetapi lebih memperhatikan keterlibatan siswa secara aktif.

Dengan demikian, maka hipotesis tindakan yang diajukan dalam penelitian ini adalah menerima hipotesis yang menyatakan dengan menggunakan model pembelajaran make a match dapat meningkatkan hasil belajar siswa pada mata pelajaran IPS materi peristiwa menjelang kemerdekaan di kelas V SD Negeri 106163 Bandar Klippa T.A 2015/2016.

\section{SIMPULAN}

Berdasarkan analisis data dan pembahasan hasil penelitian, diperoleh kesimpulan sebagai berikut:

a. Dari hasil Tes Awaldiketahui dari 25 siswa pada saat diberikan pre test tingkat ketuntasan klasikal siswa kelas $\mathrm{V}$ sebanyak 5 orang siswa (20\%) sedangkan sebanyak 20 orang siswa $(80 \%)$ belum mendapat nilai tuntas. Dengan kategori mendapat nilai rendah (20-39) sebanyak II orang siswa $(44 \%)$, mendapat nilai sedang (40-59) sebanyak 8 orang siswa $(32 \%)$, mendapat 
nilai tinggi (60-79) sebanyak 5 siswa $(20 \%)$, dan sangat tinggi $(>80)$ sebanyak I orang siswa $(4 \%)$ dengan nilai rata-rata klasikal 46,42.

b. Pada siklus I sebanyak 10 orang siswa $(40 \%)$ mendapat nilai tuntas dan 15 orang siswa $(60 \%)$ belum mendapat nilai tuntas. Dengan perincian kategori nilai rendah (20-39) sebanyak 2 siswa $(8 \%)$, mendapat nilai sedang (40-59) sebanyak 10 orang siswa $(40 \%)$, mendapat nilai tinggi (60-79) sebanyak 7 orang siswa $(28 \%)$, dan nilai sangat tinggi $(>80)$ sebanyak 6 siswa $(24 \%)$ dengan nilai rata-rata klasikal 60,01 .

c. Pada siklus sebanyak 21 orang siswa $(84 \%)$ yang mendapat nilai tuntas sedangkan sebanyak 4 orang siswa (16\%) belum mendapat nilai tuntas. Dengan perincian tidak ditemukan siswa (0\%) yang mendapat nilai rendah (20-39), tidak ditemukan yang mendapat nilai sedang (4059), mendapatkan nilai tinggi (60-79) sebanyak 5 orang siswa (20\%), dan yang mendapat nilai sangat tinggi $(>80)$ sebanyak 20 orang siswa $(80 \%)$ dengan nilai rata-rata klasikal 86,15. Bila dibandingkan dengan nilai post test pada siklus I maka dapat dikatakan terdapat peningkatan hasil belajar siswa pada siklus II sebesar $84 \%-40 \%=44 \%$, dengan demikian maka dapat dikatakan terjadi peningkatan hasil belajar siswa dari siklus I ke siklus II.

d. Berdasarkan hasil observasi aktivitas belajar siswa pada siklus I ditemukan 69,44\% persentase hasil belajar siswa, dan pada siklus II sebesar $88,88 \%$ tingkat persentase hasil belajar siswa. Dengan demikian dapat disimpulkan terdapat peningkatan aktivitas belajar siswa dari siklus I ke siklus II.

e. Hipotesis yang menyatakan dengan menggunakan model pembelajaran make a match dapat meningkatkan hasil belajar siswa pada mata pelajaran IPS materi peristiwa menjelang kemerdekaan di kelas V SD negeri 106163 Bandar Klippa.

\section{DAFTAR RUJUKAN}

Aqib, Zainal, dkk. 2010. Penelitian Tindakan Kelas. Bandung: Yrama Widya.

Bungs. 2012. Model Pembelajaran Make And Match. http://wbungs.blogspot.co.id/2 012/07/model-pembelajaranmake-and-match. Diakses Minggu, 15 Juli 2012.

Dewi, Rosmala. 2010. Penelitian Tindakan Kelas. Medan: Paska Sarjana Unimed.

Dimyati, dkk. 2013. Belajar \& Pembelajaran. Jakarta: Rineka Cipta.

Djamarah, Syaiful Bahri. 2011. Psikologi Belajar. Jakarta: Rineka Cipta.

Hartono, Rudi. 2013. Ragam Model Mengajar Yang Mudah Diterima Murid. Jakarta: Diva Press. 
Jihad, Asep. dkk. 2012. Evaluasi Pembelajaran. Yogyakarta: Multi Pressindo.

Purwanto. 2011. Evaluasi Hasil Belajar.Yogyakarta Pustaka Pelajar.

Rusman. 2010. Model-Model Pembelajaran. Jakarta: Kencana.

Shoimin, Aris. 2014. 68 Model Pembelajaran Inovatif Dalam Kurikulum 2013. Yogyakarta: Ar-ruzz Media.

Solihatin, Etin, dkk. 2008. Cooperative Learning. Jakarta: Bumi Aksara.

Slameto. 2010. Belajar dan FaktorFakıor yang Mempengaruhinya. Jakarta: Rineka Cipta.
Sudjana, Nana. 2010. Penilaian Hasil Proses Belajar Mengajar. Bandung: Remaja Rosdakarya.

Tarmizi. 2008. Pembelajaran Kooperatif Make A Match. https://tarmizi.wordpress.com/ 2008/12/03/pembelajarankooperatif-make-a-match/. Diakses 3 Desember 2008.

Tim Tunas Karya Guru, 2013. Ilmu Pengetahuan Sosial. Jakarta: Duta.

Trianto. 2011. Model Pembelajaran Terpadu. Jakarta: Kencana.

Trianto. 2012. Mendesain Model Pembelajaran Inovatif- Progresif. Jakarta: Kencana Prenada Media Group. 